WINES OF THE NEW SOUTH AFRICA 
THE PUBLISHER GRATEFULLY ACKNOWLEDGES THE GENEROUS SUPPORT OF THE GENERAL ENDOWMENT FUND OF THE UNIVERSITY OF CALIFORNIA PRESS FOUNDATION 


\section{WINES OF THE NEW SOUTH AFRICA}

Tradition and Revolution

Tim James

甲

UNIVERSITY OF CALIFORNIA PRESS

Berkeley Los Angeles London 
University of California Press, one of the most distinguished university presses in the United States, enriches lives around the world by advancing scholarship in the humanities, social sciences, and natural sciences. Its activities are supported by the UC Press Foundation and by philanthropic contributions from individuals and institutions. For more information, visit www.ucpress.edu.

University of California Press

Berkeley and Los Angeles, California

University of California Press, Ltd.

London, England

(C) 2013 by Tim James

Library of Congress Cataloging-in-Publication Data

James, Tim (Timothy James), I954 -.

Wines of the new South Africa: tradition and revolution / Tim James.

p. $\mathrm{cm}$.

Includes bibliographical references and index.

ISBN 978-0-520-26023-8 (cloth : alk. paper)

I. Wine and wine making-South Africa. I. Title.

TP559.S6J36 2013

$663^{\prime} .20968-\mathrm{dc} 23$

2012048632

Manufactured in the United States of America
$\begin{array}{llllllllll}22 & 21 & 20 & \text { I9 } & \text { I8 } & \text { I7 } & \text { I6 } & \text { I5 } & \text { I4 } & \text { I3 }\end{array}$
I0 $\quad 9 \begin{array}{lllllllll}8 & 7 & 6 & 5 & 4 & 3 & 2 & \text { I }\end{array}$

The paper used in this publication meets the minimum requirements of ANSI/NISO Z39.48-I992 (R 2002)

(Permanence of Paper). 
To Louise and Eben 
